Uygulamalı Yerbilimleri Dergisi

Cilt: 16, No: 2, 2017 (29-41)

Journal of Applied Earthsciences

Vol: 16, No: 2, 2017 (29-41)

\title{
Geophysical and Geotechnical Studies for Electric Power Plants Project at the Sakarya River Zone, Turkey
}

\author{
Cengiz KURTULUŞ ${ }^{1}$, Ali BOZKURT ${ }^{2}$, Hasan ENDEŞ ${ }^{3}$ and İsmail Talih GÜVEN ${ }^{4}$
}

\begin{abstract}
Geophysical and geotechnical studies were conducted at a proposed hydroelectric power plants facility at a site north of Sakarya river D100(E-5) bridge in Adapazarı town of Sakarya city in Turkey. The study is aimed at evaluating the competence of the near surface formation as foundation materials. Geophysical and geotechnical methods of investigation were adopted. The geophysical investigation involved the Vertical Electrical Sounding (VES) technique using the Schlumberger configuration, seismic refraction and geotechnical investigative methods comprised of boreholes to $40 \mathrm{~m}$ depth with Standard Penetrating Testing (SPT) and undisturbed Shelby tube, disturbed Split Spoon soil sampling, triaxial compresssion and consolidation tests. A total of five Vertical Electrical Soundings (VES) and five seismic refraction profiles from different location within the study area were used for the study. Water content, plasticity, and grain size distribution characteristics are obtained from laboratory testing leading to a classification of soils using the Unified Classification System. The geophysical results revealed three distinct geoelectric sequences which comprises of topsoil, weathered and partially weathered layers. The topsoils composed of clay/silt/sand while the weathered layer composed of silty sand. The partially weathered layer is formed of silty clay. The geotechnical results show that the partly weathered layer has relatively high clay content. Based on the consistency limits of the soils within the area, the soil generally indicate firm plasticity, hence, the soils are expected to exhibit medium swelling potential. There is no evident of geological feature such as fracture/fault within the subsoil in the area.
\end{abstract}

\section{Introduction}

Geophysical methods such as the seismic refraction and electrical resistivity (RC) are used for the site investigation. Geophysical surveys are efficient and cost-effective in providing geotechnical information since they combine high-speed and accuracy in providing subsurface information over large areas (Wang 1979; Seed et al. 1983; Luna and Jadi 2000: Soupios et al. 2005; Momoh et al. 2008; Ozcep et al. 2009; Akin Torinwa OJ et al. 2009; Bozkurt and Kurtulus 2009; Kurtulus et al. 2010). Site characterization is carried out for the construction of hydroelectric power plants in the Sakarya region located in the earthquake-prone areas to determine depth of bedrock, structural mapping and evaluation of subsoil competence. The need to provide information in the subsurface sequence and structure deposition necessary for foundation design needed an integrated geophysical and geotechnical investigations of the area. As a part of investigation, measurements of relevant dynamic parameters both in laboratory and in situ have been made for determination of dynamic deformation and dynamic soil structure analysis.

\section{Description of the Environment of the Investigated Site}

The study area is located within Adapazari town north of D100 (E-5) Bridge (Fig.1). The topography is low lying. The site is located within the climate of Marmara region. The main annual temperature is $14^{\circ}$ while the rainfall varies between $38-114 \mathrm{~mm}$ (General directorate of Meteorology of Turkey).Alluviums composed of clay; sand and silt are the major outcrop that occur within the study area.

\footnotetext{
${ }^{1}$ Kocaeli University, Engineering Faculty, Department of Geophysics, Kocaeli, Turkey

${ }^{22}$ ABM Engineering Co., Izmit, Kocaeli, Turkey

${ }^{3}$ Kocaeli University, Engineering Faculty, Department of Geophysics, Kocaeli, Turkey

${ }^{4}$ Kocaeli University, Architectural and Design Faculty, Kocaeli, İzmit

*ilgili yazar / Corresponding author: emremazak@gmail.com
}

Gönderim Tarihi: 20.04.2017

Kabul Tarihi: 30.05.2017 


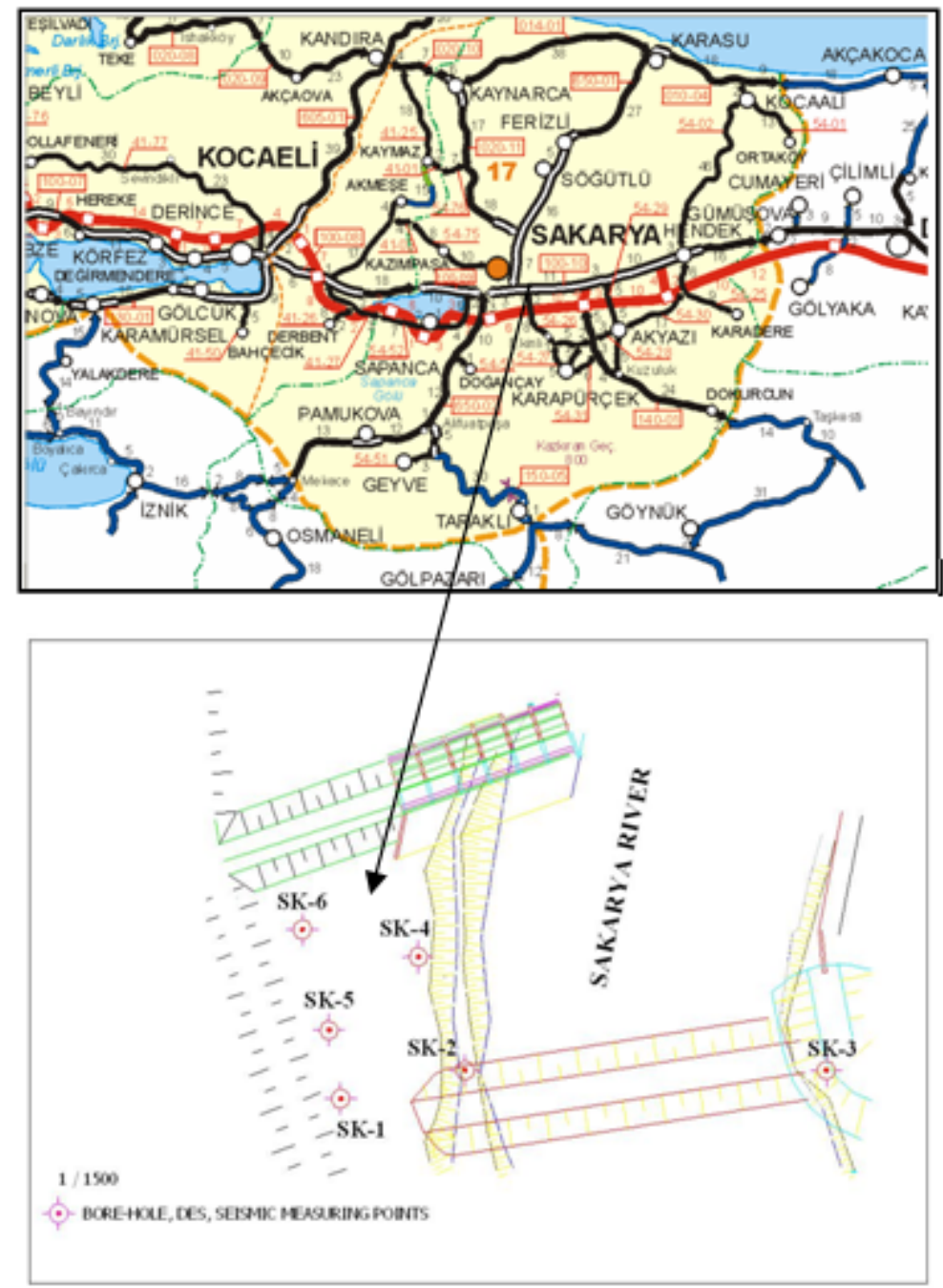

Fig.1: Location map of the investigation area

\section{Methodology}

Seismic refraction surveys are performed at five stations in the investigation area. The seismic data were recorded by a 12 channel Geometrics Seismic Enhancement (Smart Seis) recorder with a $8 \mathrm{~Hz}$ geophone system. A seismic hammer of $8 \mathrm{~kg}$ was used as an energy source. The measurements were conducted using offset and geophone intervals at $2 \mathrm{~m}$. The geophone coupling was achieved very well and the surface noises were filtered as much as possible to improve the data quality.

The seismic refraction seismograms were interpreted using GeoSeis computer program. The best fit lines of the first brakes of the signals were determined. The P-and S-wave velocities were computed from the slope of these best fit lines.

A total of five Vertical Electrical Soundings (VES) were conducted at five stations using the Schlumberger configuration. The electrode spacing was opened as much as (AB/2) 60m. The apparent resistivity values were plotted against electrode spacing $(\mathrm{AB} / 2)$ on a bi-logarithmic graph sheet to generate depth sounding curves. Partial curve matching was carried out on the field curves. The interpretation results (layer resistivity and thickness) were fed into computer for 1-D computer assisted 
interpretation involving IPI software. The final interpreted results were used for the preparation of geoelectric sections.

A total of 6 drill holes, were drilled at the depth ranges between $38.0 \mathrm{~m}$ and $40.0 \mathrm{~m}$ to figure out the subsurface layers and their geotechnical properties.

Undisturbed (UD) and disturbed (SPT) soil samples were collected at every $1.5 \mathrm{~m}$ of depth in the boreholes (SK-2, SK-4 and SK-5) as shown in Fig. 1. These samples were preserved in polythene bags and transported to the laboratory within a period of 24 hours after collection. These samples were air dried by spreading them out on trays in a worm room for four days. Geotechnical tests including grain size analysis, Atterberg limits, consolidation and triaxial tests were conducted. Pressiometer tests were applied at the boring holes SK-1, SK-3 and SK-6 to figure out the mechanical properties of the soil layers.

\section{RESULTS AND DISCUSSION}

\section{Geophysical Results}

\section{Seismic results}

Reciprocal seismic refraction studies were conducted. Three layers were identified and their P-and Swave velocities, and thicknesses were determined from the seismic studies. The topsoil deposits clay/silt/sand with the thickness varies between $3,78 \mathrm{~m}$ and $4,52 \mathrm{~m}$, and P-and S- wave velocities 561$644 \mathrm{~m} / \mathrm{s}$ and $204-234 \mathrm{~m} / \mathrm{s}$ respectively were obtained. Below this layer of P- and S- wave velocities $672-776 \mathrm{~m} / \mathrm{s}$ and $256-296 \mathrm{~m} / \mathrm{s}$ respectively, the stratum is medium-hard consistency silty sand with the thickness of $11.5-14.5 \mathrm{~m}$ underlain by the third layer formed of hard consistency silty clayey sand with P- and S- wave velocities ranged between $842-909 \mathrm{~m} / \mathrm{s}$ and $330-357 \mathrm{~m} / \mathrm{s}$ respectively (Fig 2). The dynamic properties related to these layers are given in Table 1.

Table 1. Dynamic properties of the soils

\begin{tabular}{|c|c|c|c|c|c|c|c|c|c|c|c|c|c|}
\hline $\begin{array}{c}\text { Profile } \\
\text { No }\end{array}$ & $\begin{array}{c}\text { Layer } \\
\text { No }\end{array}$ & $\begin{array}{c}\mathrm{Vp} \\
(\mathrm{m} / \mathrm{s})\end{array}$ & $\begin{array}{c}\text { Vs } \\
(\mathrm{m} / \mathrm{s})\end{array}$ & $\begin{array}{c}\rho \\
\left(\mathrm{gr} / \mathrm{cm}^{3}\right)\end{array}$ & $\begin{array}{c}E \\
\left(\mathrm{~kg} / \mathrm{cm}^{2}\right)\end{array}$ & $\begin{array}{c}\mathrm{G} \\
\left(\mathrm{kg} / \mathrm{cm}^{2}\right)\end{array}$ & $\sigma$ & $\begin{array}{l}\text { h1 } \\
\text { (m) }\end{array}$ & $\begin{array}{l}\text { h2 } \\
\text { (m) }\end{array}$ & $\begin{array}{c}\mathrm{K} \\
\left(\mathrm{kg} / \mathrm{cm}^{2}\right)\end{array}$ & $\begin{array}{c}\text { qS } \\
\left(\mathrm{kg} / \mathrm{cm}^{2}\right)\end{array}$ & $\mathbf{a}$ & $\begin{array}{l}\text { To } \\
\text { (s) }\end{array}$ \\
\hline \multirow{3}{*}{ Sis-1 } & I & 561 & 204 & 1,71 & 2030 & 713 & 0,42 & \multirow{3}{*}{4,09} & \multirow{3}{*}{$\begin{array}{c}14,4 \\
5\end{array}$} & 4442 & 0,84 & \multirow{3}{*}{3,0} & \multirow{3}{*}{0,62} \\
\hline & II & 672 & 256 & 1,73 & 3225 & 1140 & 0,41 & & & 6303 & 1,07 & & \\
\hline & III & 909 & 357 & 1,78 & 6385 & 2265 & 0,41 & & & 11711 & 1,52 & & \\
\hline \multirow{3}{*}{ Sis-2 } & $\mathrm{I}$ & 618 & 225 & 1,72 & 2477 & 870 & 0,42 & \multirow{3}{*}{3,78} & \multirow{3}{*}{$\begin{array}{c}13,4 \\
1\end{array}$} & 5419 & 0,93 & \multirow{3}{*}{3,0} & \multirow{3}{*}{0,62} \\
\hline & II & 753 & 287 & 1,75 & 4093 & 1447 & 0,41 & & & 8001 & 1,21 & & \\
\hline & III & 857 & 336 & 1,77 & 5641 & 2002 & 0,41 & & & 10346 & 1,43 & & \\
\hline \multirow{3}{*}{ Sis-3 } & $\mathrm{I}$ & 644 & 234 & 1,73 & 2703 & 949 & 0,42 & \multirow{3}{*}{4,52} & \multirow{3}{*}{$\begin{array}{c}13,5 \\
3\end{array}$} & 5913 & 0,97 & \multirow{3}{*}{3,0} & \multirow{3}{*}{0,62} \\
\hline & II & 744 & 284 & 1,75 & 3988 & 1409 & 0,41 & & & 7796 & 1,19 & & \\
\hline & III & 872 & 342 & 1,77 & 5849 & 2075 & 0,41 & & & 10728 & 1,46 & & \\
\hline \multirow{3}{*}{ Sis-4 } & $\mathrm{I}$ & 595 & 216 & 1,72 & 2288 & 804 & 0,42 & \multirow{3}{*}{4,16} & \multirow{3}{*}{$\begin{array}{c}14,4 \\
1\end{array}$} & 5006 & 0,89 & \multirow{3}{*}{3,0} & \multirow{3}{*}{0,62} \\
\hline & II & 776 & 296 & 1,76 & 4362 & 1542 & 0,41 & & & 8528 & 1,25 & & \\
\hline & III & 849 & 333 & 1,77 & 5528 & 1962 & 0,41 & & & 10140 & 1,41 & & \\
\hline \multirow{3}{*}{ Sis-5 } & $\mathrm{I}$ & 565 & 205 & 1,71 & 2057 & 722 & 0,42 & \multirow{3}{*}{3,95} & \multirow{3}{*}{$\begin{array}{c}11,5 \\
3\end{array}$} & 4500 & 0,84 & \multirow{3}{*}{3,0} & \multirow{3}{*}{0,63} \\
\hline & II & 738 & 282 & 1,75 & 3927 & 1388 & 0,41 & & & 7676 & 1,18 & & \\
\hline & III & 842 & 330 & 1,77 & 5429 & 1926 & 0,41 & & & 9958 & 1,40 & & \\
\hline
\end{tabular}




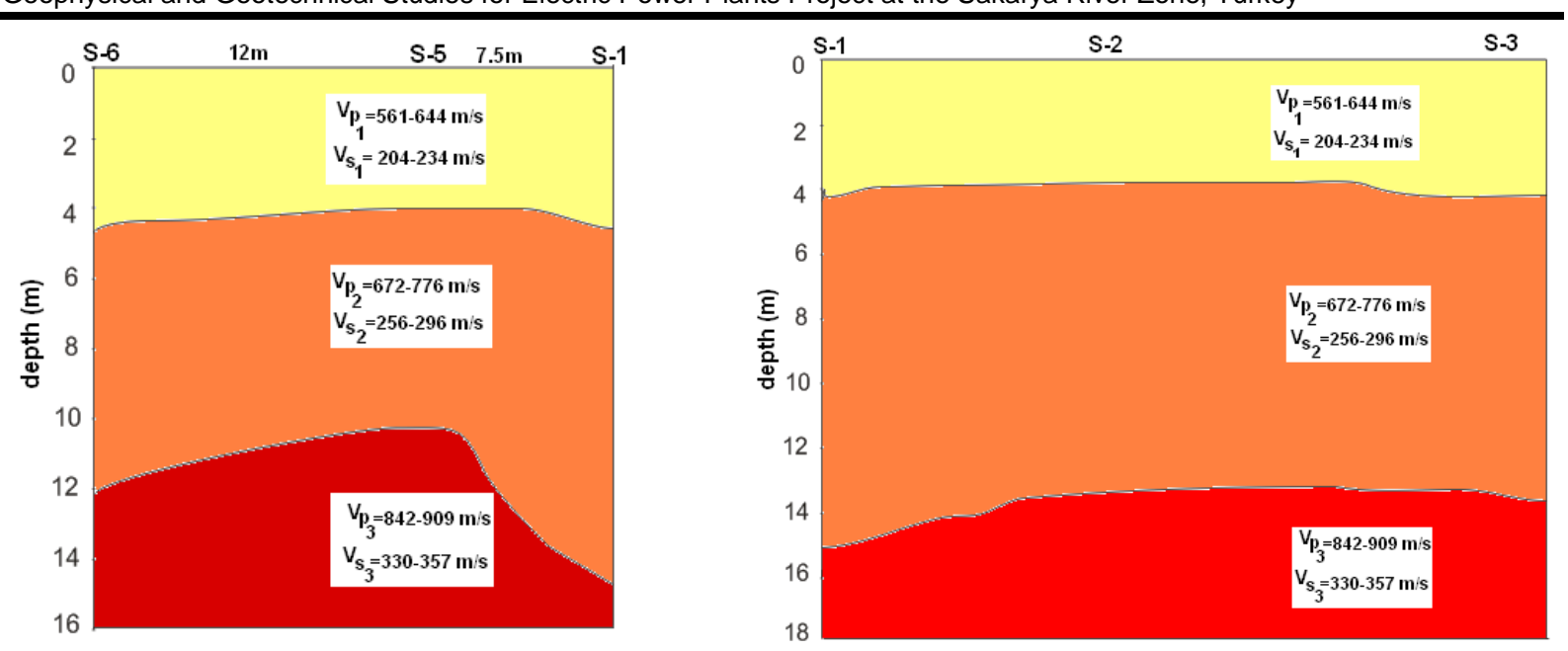

Fig. 2. Seismic cross sections: (a) through SK-6 and SK-1, (b) SK-1 and SK-3
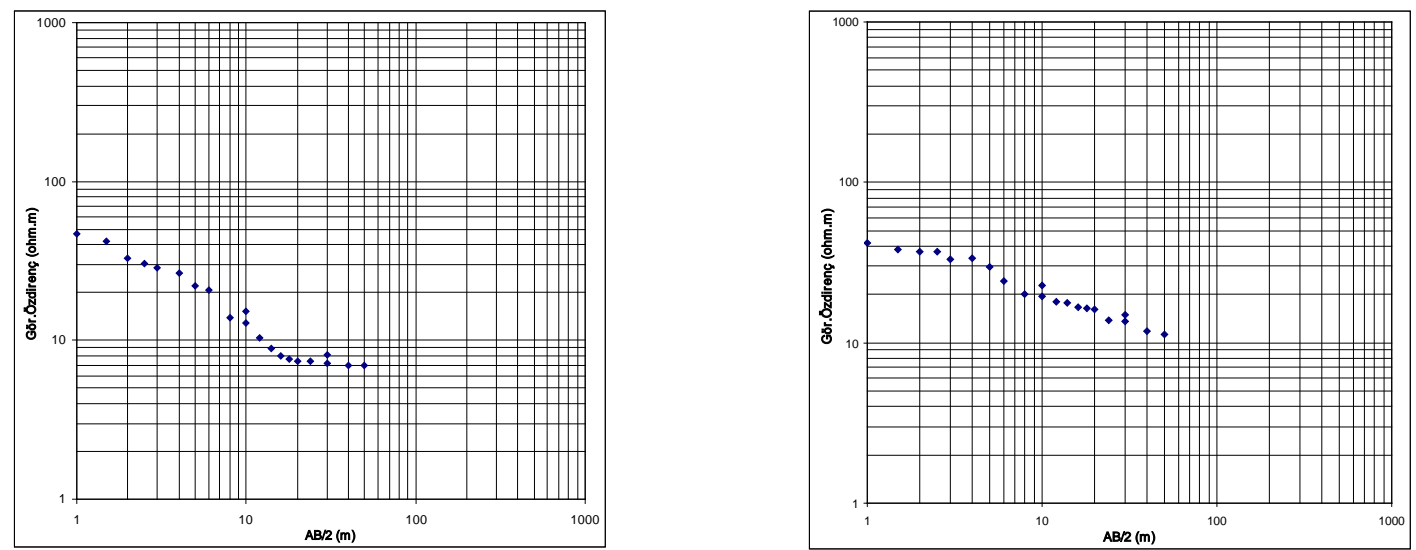

Fig. 3. Resistivity curves (a) for RES-3, ( b) for RES-5

\section{Geoelectric Parameters}

The VES interpretation results were used (Fig. 3) to prepare 2-D geoelectric sections illustrated in Fig. 4. The geoelectric sections describe maximum of three geologic subsurface layers comprising the topsoil, weathered and partly weathered layer. The topsoil is composed of clay/silt/sand with resistivity values range from 18 to $45 \Omega \mathrm{m}$ and thickness of between $0.90-1.51 \mathrm{~m}$. The weathered layer consists of silty sand with the resistivity value ranging between $19-52 \Omega \mathrm{m}$ and partly weathered layer is composed of silty clayey sand with the resistivity values range from 7 to $12 \Omega \mathrm{m}$.

Where Vp and Vs are the P- and S-wave velocities, $\rho$ : density, E: elasticity modulus, G: Shear modulus, $\sigma$ : Poisson's ration, $\mathrm{h}_{1}$ and $\mathrm{h}_{2}$ : Thicknesses of the first and second layers, K: Bearing coefficient, qs : Safety bearing capacity, a: Soil magnification, To: Natural soil period. 

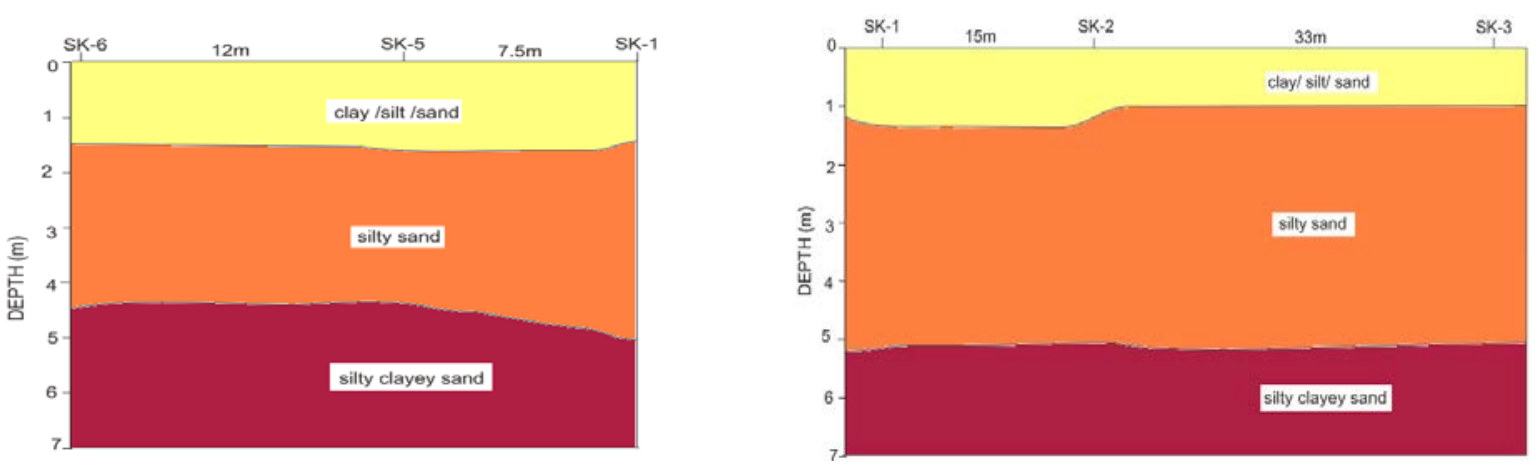

Fig. 4. Geoelectrical cross sections (a) through SK-6 and SK-1, (b) SK-1 and SK-3

\section{Correlation of Seismic refraction and Electrical Resistivity Geoelectrical Sections}

Seismic refraction sections and resistivity geoelectrical sections (Figs 2 and 4) were prepared along the same traverses (SK-6- SK-1, and SK-1-SK-3). Comparison of the figures shows that even though the geoelectrical sections look alike, the depth variations for topsoil $2.5-3.0 \mathrm{~m}$, for weathered layer $5-6 \mathrm{~m}$ exist between the seismic refraction and electrical results. This may be due to the fact that two methods respond to different properties of soil.

\section{Geotechnical Results}

\section{Index results}

Fig. 5 shows the SPT values obtained in bore-hole SK-4 which are very similar to the SPT values of other bore holes. The $\mathrm{N}_{30}$ values vary between 23 and 30 indicating that the consistency of the formations ranges from stiff to hard (Peck et al. 1953).

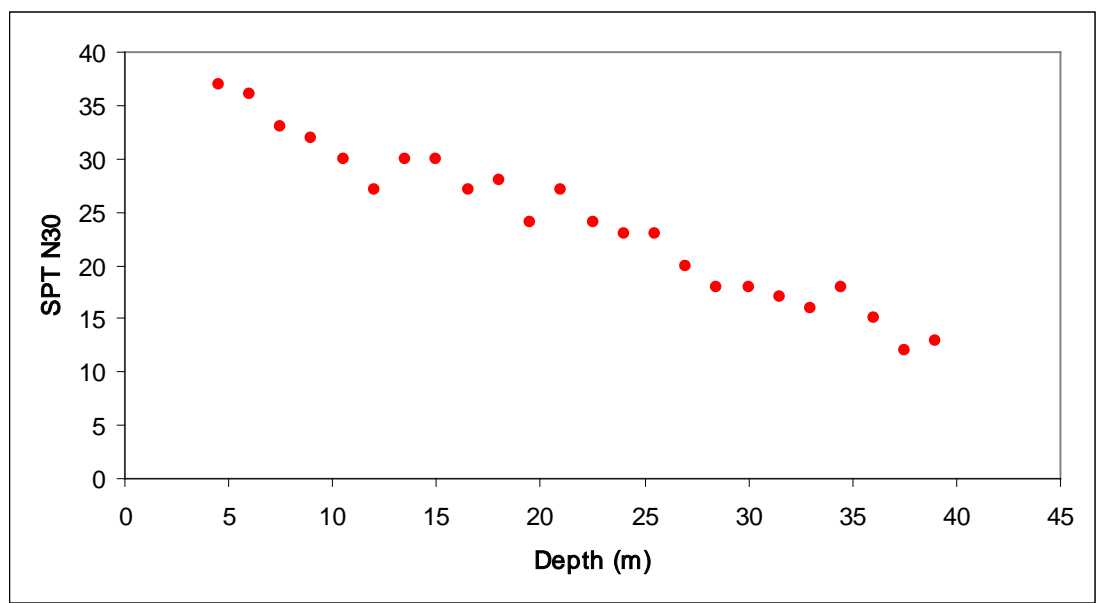

Fig. 5. Variation of SPT N30 values with depth

Table 2 shows the summary of geotechnical results of the SPT and UD samples collected from borehole SK-5. The natural water content of tested soil samples varies between 19.65 and $34.0 \%$. This indicates that the natural water content of the soil in this area is of medium at its natural state. From the grading curves (Fig. 6) the soils can be classified as well graded soil. The tested soils have percentage finer (percentage passing $0.075 \mathrm{~mm}$ ) varies between $15.75 \%$ and $95.05 \%$. the soils that are largely made up of fine particles are likely to have poor geotechnical properties as foundation materials than soils that are largely made up of coarse particle. 
Geophysical and Geotechnical Studies for Electric Power Plants Project at the Sakarya River Zone, Turkey

\begin{tabular}{|c|c|c|c|c|c|c|c|c|c|c|c|c|c|c|}
\hline \multirow{4}{*}{ 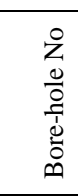 } & \multirow{4}{*}{ 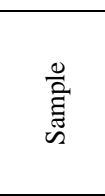 } & \multirow{4}{*}{ 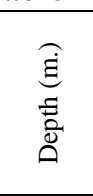 } & \multirow{4}{*}{ 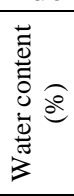 } & \multirow{4}{*}{$\begin{array}{l}n \\
\frac{n}{0} \\
=\overline{0} \\
\omega\end{array}$} & \multirow{2}{*}{\multicolumn{3}{|c|}{ Atterberg limits }} & \multirow{4}{*}{ 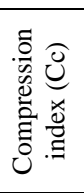 } & \multirow{4}{*}{ 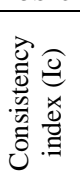 } & \multirow{4}{*}{ 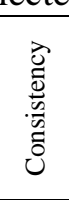 } & \multirow{4}{*}{ 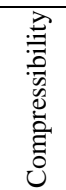 } & \multirow{4}{*}{$\begin{array}{l}\stackrel{\infty}{\Xi} \\
\overline{\overline{0}} \\
\omega^{3}\end{array}$} & \multirow{4}{*}{ 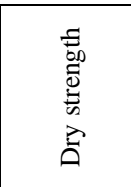 } & \multirow{4}{*}{ 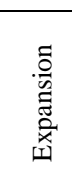 } \\
\hline & & & & & & & & & & & & & & \\
\hline & & & & & LL & PL & PI & & & & & & & \\
\hline & & & & & (\%) & (\%) & (\%) & & & & & & & \\
\hline SK-5 & SPT-1 & $\begin{array}{l}4.50- \\
4.95\end{array}$ & 19.65 & SM & & NP & & & & & & & & \\
\hline SK-5 & SPT-3 & $\begin{array}{l}7.50- \\
7.95\end{array}$ & 21.5 & SM & & NP & & & & & & & & \\
\hline SK-5 & SPT-6 & $\begin{array}{l}12.00- \\
12.45\end{array}$ & 29.76 & CL & 47.50 & 19.62 & 27.88 & 0.43 & 0.64 & stiff & high & medium & $\begin{array}{l}\text { Medium- } \\
\text { high }\end{array}$ & $\begin{array}{l}\text { Not- } \\
\text { very } \\
\text { slow }\end{array}$ \\
\hline SK-5 & UD-1 & $\begin{array}{l}16.00- \\
16.50\end{array}$ & 27.45 & CL & 46.24 & 21.01 & 25.23 & 0.42 & 0.74 & stiff & high & medium & $\begin{array}{l}\text { Medium- } \\
\text { high }\end{array}$ & $\begin{array}{l}\text { Not- } \\
\text { very } \\
\text { slow }\end{array}$ \\
\hline SK-5 & UD-2 & $\begin{array}{c}17.50- \\
18.00 \\
\end{array}$ & $\begin{array}{c}34.00 \\
5 \\
\end{array}$ & $\mathrm{CH}$ & 53.37 & 19.21 & 34.16 & 0.48 & 0.57 & stiff & high & medium & $\begin{array}{c}\text { high- } \\
\text { Very high }\end{array}$ & $\begin{array}{c}\text { Slow- } \\
\text { not }\end{array}$ \\
\hline SK-5 & SPT-12 & $\begin{array}{l}21.00- \\
21.45\end{array}$ & 31.07 & $\mathrm{CH}$ & 52.04 & 18.72 & 33.32 & 0.47 & 0.63 & stiff & high & medium & $\begin{array}{c}\text { high- } \\
\text { Very high }\end{array}$ & $\begin{array}{c}\begin{array}{c}\text { Slow- } \\
\text { not }\end{array} \\
\end{array}$ \\
\hline SK-5 & YSK-5 & $\begin{array}{l}24.00- \\
24.45\end{array}$ & 27.18 & $\mathrm{CH}$ & 57.56 & 21.39 & 36.17 & 0.52 & 0.84 & stiff & high & $\begin{array}{l}\text { high- } \\
\text { Very } \\
\text { high }\end{array}$ & $\begin{array}{c}\text { high- } \\
\text { Very high }\end{array}$ & $\begin{array}{c}\text { Slow- } \\
\text { not }\end{array}$ \\
\hline SK-5 & UD-3 & $\begin{array}{l}28.00- \\
28.50 \\
\end{array}$ & 28.85 & $\mathrm{CH}$ & 51.34 & 20.81 & 30.53 & 0.46 & 0.74 & stiff & high & medium & $\begin{array}{c}\text { high- } \\
\text { Very high }\end{array}$ & $\begin{array}{c}\text { Slow- } \\
\text { not }\end{array}$ \\
\hline SK-5 & UD-4 & $\begin{array}{l}36.50- \\
37.00\end{array}$ & 26.3 & CL & 47.50 & 20.79 & 26.71 & 0.43 & 0.79 & stiff & high & medium & $\begin{array}{l}\text { Medium- } \\
\text { high }\end{array}$ & $\begin{array}{l}\text { Not- } \\
\text { very } \\
\text { slow }\end{array}$ \\
\hline
\end{tabular}

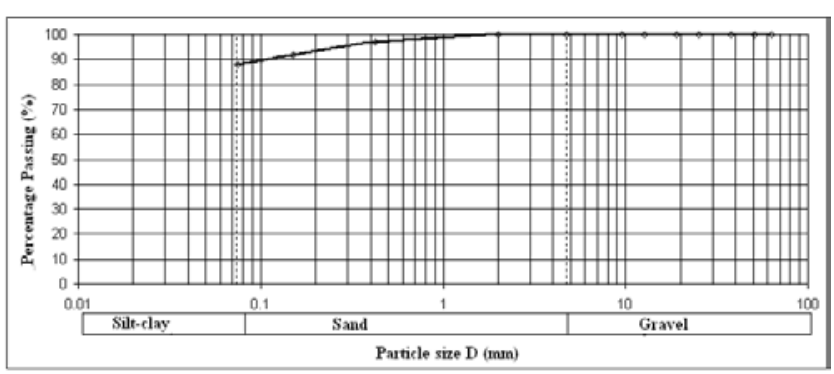

Fig. 6. Typical grain size distribution curve

As shown in Table 2. the liquid limit of the soil samples range from 46.24-57.56\%, the plastic limit varies between $19.62-21.39 \%$, and the plasticity index ranges from 26.71-36.17\%. The tested soil samples are of hard consistency limits indicating high percentage of clay content in the soil. Generally, soils having high values of liquid and plastic limits are considered poor as foundation materials.

The compressibility index of the soil samples ranges from 0.63-0.84 indicating that the compressibility of the soil is high ( Sowers 1979), (Table 2). The plasticity index of the soil samples varies between 25.23-36.17 indicating that the soils are 'plastic-very plastic' and have the dry consistency as 'medium-high' (Leonards 1972). The range of plasticity index shows that the swelling degree of the soil is 'medium-high' (Gibs and Holtz 1956). The dry consistency of the soils 'medium-high' for CLclass, ‘high-very high’ for $\mathrm{CH}$-class.

\section{Groundwater and Surface Water}

The soils in the investigation area have different groundwater potential depending on their lithologic and fine grained ratio. The groundwater readings were performed within 24 hours after the end of drillings. The groundwater levels of the bore-holes range from $2.0-6.70 \mathrm{~m}$ as shown in Table 3. The water samples collected from the bore-holes were analyzed to investigate harmfulness in term of concrete and steel. The analysis of the results is given in Table 4. 
Table 3. Groundwater levels in the bore-holes

\begin{tabular}{|c|c|c|c|}
\hline Bore-hole No & Ground water level (m) & Bore-hole No & Ground water level (m) \\
\hline SK-1 & 6,70 & SK-4 & 6,50 \\
\hline SK-2 & 3,00 & SK-5 & 6,50 \\
\hline SK-3 & 2,00 & SK-6 & 6,00 \\
\hline
\end{tabular}

Table 4. The results of analysis of water samples collected from the boreholes

\begin{tabular}{|c|c|c|c|c|c|c|c|}
\hline Parameters & SK-1 & SK-4 & SK-5 & SK-6 & Up stream & $\begin{array}{l}\text { Down } \\
\text { stream }\end{array}$ & $\begin{array}{l}\text { TS } 266 \text { Limit } \\
\text { values }\end{array}$ \\
\hline $\mathrm{PH}$ & 7,45 & 7,28 & 7,33 & 7,21 & 7,12 & 7,24 & $6,5-9,2$ \\
\hline $\begin{array}{l}\text { Dissolved oxygen } \\
\mathrm{mg} / \mathrm{lt} \text {. }\end{array}$ & 9,6 & 9,3 & 9,8 & 8,6 & 1,3 & 1,8 & - \\
\hline $\begin{array}{l}\text { Organic matter } \\
\mathrm{mgO}_{2} / \text { lt. }\end{array}$ & 3,3 & 3,1 & 2,9 & 2,3 & 3,4 & 3,2 & 3,5 \\
\hline $\begin{array}{l}\text { Total hardness } \\
\mathrm{CaCO}_{3} \text { (mg/lt) }\end{array}$ & 240 & 250 & 230 & 260 & 90 & 80 & 500 \\
\hline Coliform & 38 & 33 & 42 & 36 & 45 & 48 & 50 \\
\hline
\end{tabular}

\section{Permeability Test}

The soil samples collected from bore-hole SK-2 (23.50-24m), SK-4 (16.0-16.50m) and SK-5 (17.50$18 \mathrm{~m}$ ) were subjected the fixed-level permeability test. The permeability coefficients were determined for these bore-holes as $5.06 \times 10^{-8} \mathrm{~cm} / \mathrm{s}, 6.00 \times 10^{-8} \mathrm{~cm} / \mathrm{s}$ and $5.92 \times 10^{-8} \mathrm{~cm} / \mathrm{s}$ respectively and interpreted as 'not permeable-very low permeable'.

\section{Triaxial test results}

Triaxial test was conducted on the UD soil samples collected from different depths of the bore-holes (SK-2, SK-4, SK-5) as shown in Table 5. The cohesion of the soil samples was determined between 38.0 and $53.0 \mathrm{kPa}$ and angle of internal friction was obtained between $2^{\circ}$ and $4^{\circ}$.

Table 5. Triaxial test results

\begin{tabular}{|c|c|c|c|c|}
\hline Bore- hole No & Sample type & Depth $(\mathrm{m})$ & Cohesion $(\mathrm{kPa})$ & Internal friction angle $(\Phi)$ \\
\hline SK-2 & UD-1 & $14.00-14.50$ & 40 & 2 \\
\hline SK-2 & UD-2 & $17.00-17.50$ & 43 & 2 \\
\hline SK-2 & UD-3 & $23.50-24.00$ & 47 & 3 \\
\hline SK-4 & UD-1 & $12.50-13.00$ & 38 & 2 \\
\hline SK-4 & UD-2 & $16.00-16.50$ & 44 & 3 \\
\hline SK-5 & UD-2 & $17.50-18.00$ & 41 & 4 \\
\hline SK-5 & UD-3 & $28.00-28.50$ & 53 & \\
\hline
\end{tabular}

\section{Consolidation properties}

Consolidation properties of the soils were conducted on 7 undisturbed samples, collected from $12.50 \mathrm{~m}$ to a depth of $28.50 \mathrm{~m}$, using the odometer device based on ASTM (1985) standards. Graphics of pressure (logarithmic) - void ratio were drawn using the data obtained from tests. Consolidation coefficient (Cv), volumetric compression coefficient (Mv) and compression indices (Cc : compression index and $\mathrm{Cr}$ : recompression index) were determined from these graphics. Over consolidation ratio 
Geophysical and Geotechnical Studies for Electric Power Plants Project at the Sakarya River Zone, Turkey

(OCR) was computed dividing preconsolidation pressure (Pc) to initial effective vertical stress (Po). Preconsolidation pressure and compression indices were graphically determined. The preconsolidation pressure was determined from the laboratory curves by the procedure proposed by Casagrande (Table $6)$.

Table 6. Consolidation parameters

\begin{tabular}{|c|c|l|c|c|c|c|c|c|}
\hline Bore-hole No: & Sample & \multicolumn{1}{|c|}{ Depth $(\mathrm{m})$} & $\mathrm{P}_{\mathrm{o}}$ & $\mathrm{P}_{\mathrm{c}}$ & $\mathrm{OCR}$ & $\mathrm{e}_{\mathrm{o}}$ & $\mathrm{C}_{\mathrm{r}}$ & $\mathrm{C}_{\mathrm{c}}$ \\
\hline SK-4 & UD-1 & $12.5-13.0$ & 0.19 & 1.8 & 9.47 & 1.04 & 0.082 & 0.195 \\
\hline SK-4 & UD-2 & $16.0-16-50$ & 0.86 & 2.8 & 3.25 & 1.16 & 0.073 & 0.163 \\
\hline SK-5 & UD-2 & $17.50-18.00$ & 0.82 & 3.1 & 3.78 & 1.03 & 0.07 & 0.218 \\
\hline SK-2 & UD-3 & $23.5-24.0$ & 0.85 & 4.0 & 4.7 & 0.95 & 0.082 & 0.146 \\
\hline SK-5 & UD-3 & $28.0-28.5$ & 0.91 & 3.8 & 4.11 & 0.83 & 0.072 & 0.168 \\
\hline
\end{tabular}

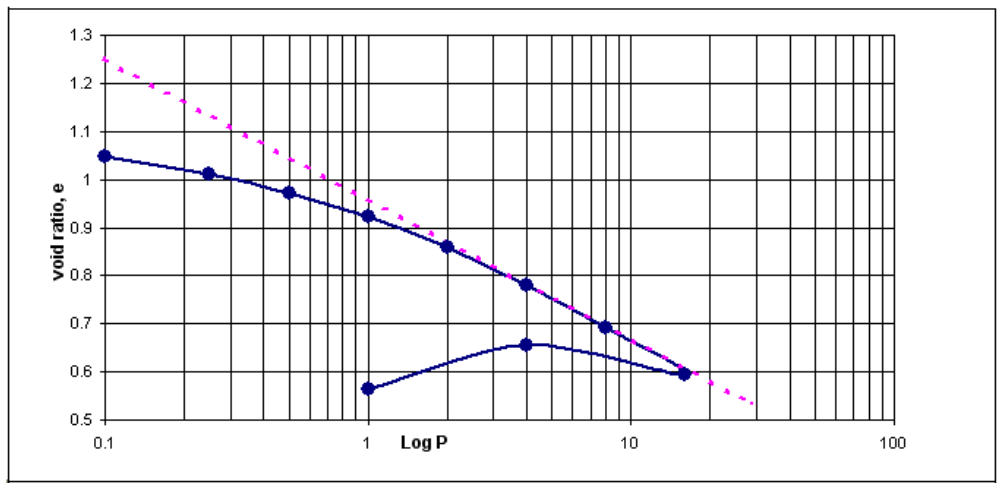

Fig. 7. e-logP graphic of consolidation test for bore-hole SK-2

The coefficients of consolidation (Cv) were obtained from the laboratory tests for various depths.

For a pressure interval of $1-4 \mathrm{~kg} / \mathrm{cm}^{2}$, an average $(\mathrm{Cv})$ value for consolidation settlement time is taken as $0.0089 \mathrm{~cm}^{2} / \mathrm{s}$. The $\mathrm{Cv}$ values are within the range of $0.0075-0.02 \mathrm{~cm}^{2} / \mathrm{s}$ for the loads $0.1-16 \mathrm{~kg} /$ $\mathrm{cm}^{2}$ and do not show any relationship with depth (Table 7).

Table 7. Consolidation test results for bore-hole SK-2

\begin{tabular}{|c|c|c|c|c|c|c|c|c|c|c|}
\hline $\begin{array}{c}\text { Specific gravity } \\
\text { Gs }=2.68\end{array}$ & \multicolumn{2}{|c|}{$\begin{array}{c}\text { Water content } \\
\text { W= } 20.99\end{array}$} & \multicolumn{2}{|c|}{$\begin{array}{c}\text { Final void ratio } \\
\text { ef }=0.5625\end{array}$} & \multicolumn{3}{|c|}{$\begin{array}{c}\text { First sample height } \\
\mathrm{H}_{0}=20 \mathrm{~mm}\end{array}$} & \multicolumn{3}{|c|}{$\begin{array}{c}\text { Compression index } \\
\text { Cc }=0.29\end{array}$} \\
\hline Load $\left(\mathrm{kg} / \mathrm{cm}^{2}\right)$ & 0.1 & 0.25 & 0.5 & 1 & 2 & 4 & 8 & 16 & 4 & 1 \\
\hline $\mathrm{H}_{0}(\mathrm{~mm})$ & 20 & 19.28 & 18.95 & 18.58 & 18.1 & 17.5 & 16.77 & 15.95 & 15.01 & 15.59 \\
\hline Last reading & 72 & 105 & 142 & 190 & 250 & 323 & 405 & 499 & 441 & 528 \\
\hline $\mathrm{dH}(\mathrm{mm})$ & 0.72 & 0.33 & 0.37 & 0.48 & 0.6 & 0.73 & 0.82 & 0.94 & -0.58 & 0.87 \\
\hline Hf (mm) & 19.28 & 18.95 & 18.58 & 18.1 & 17.5 & 16.77 & 15.95 & 15.01 & 15.59 & 14.72 \\
\hline de & 0.076 & 0.035 & 0.039 & 0.05 & 0.063 & 0.077 & 0.087 & 0.0998 & -0.061 & 0.09 \\
\hline Void ratio (e) & 1.047 & 1.011 & 10.97 & 0.92 & 0.86 & 0.78 & 0.69 & 0.59 & 0.65 & 0.56 \\
\hline $\begin{array}{c}\text { Compressibility } a_{v} \\
\left(\mathrm{~cm}^{2} / \mathrm{kg}\right)\end{array}$ & 0.23 & 0.16 & 0.1 & 0.063 & 0.087 & 0.0217 & 0.012 & 0.0051 & & \\
\hline $\begin{array}{c}\text { Volumetric } \\
\text { compression mv } \\
\left(\mathrm{cm}^{2} / \mathrm{kgf}\right)\end{array}$ & 0.11 & 0.078 & 0.051 & 0.033 & 0.0387 & 0.012 & 0.0074 & 0.0032 & & \\
\hline $\begin{array}{c}\text { Consolidation time } \\
\mathrm{T}_{90}(\mathrm{~min})\end{array}$ & 42.15 & 39.01 & $\begin{array}{c}30.737 \\
7.41\end{array}$ & 66.89 & 80.36 & 81.42 & 66.12 & 73.53 & & \\
\hline $\begin{array}{l}\text { Cons. Coef. } \mathrm{C}_{\mathrm{v}} \\
\text { (cm2/min) }\end{array}$ & 0.020 & 0.02 & 0.0098 & 0.01 & 0.0086 & 0.0079 & 0.009 & 0.007 & & \\
\hline
\end{tabular}

Where $\mathrm{H}_{0}$ : thickness variation, $\mathrm{dH}$ : height at the end of the experiment, de: void ratio variation. The eLogP graphic of the consolidation test is given in Fig 7. As seen from the graphic that the void ratio (e) is found as $\mathrm{e}=1.25$ for point load $0.1 \mathrm{~kg} / \mathrm{cm}^{2}$, and $\mathrm{e}=0.534$ for point load $29 \mathrm{~kg} / \mathrm{cm}^{2}$. 
Bearing Capacity

The minimum bearing capacity of the soil was figured out as qu=3.68 kg/ $\mathrm{cm}^{3}$ considering $\mathrm{C}=40 \mathrm{kPa}$, $\Phi=2^{0}$ and $\mathrm{Nc}=5.63, \mathrm{Nq}=1.20, \mathrm{~N} \gamma=0.01$ and $\mathrm{B}=45.0 \mathrm{~m}, \mathrm{Df}=20.0 \mathrm{~m}, \mathrm{~K} 1=1.12$ and $\mathrm{K} 2=0.46$ in Terzaghi's equation .

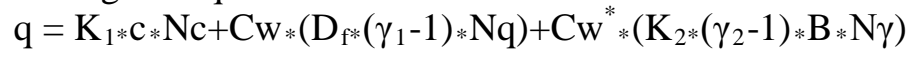

where

qu : Bearing capacty

c : Cohesion

Nc, Nq, Ny : Coefficients of bearing capacity

$\mathrm{D}_{\mathrm{f}}$ : Foundation depth

B : Foundation width

$\gamma_{\mathrm{n}}:$ Unit weight

$\mathrm{K}_{1}-\mathrm{K}_{2}$ : Coefficient related to foundation shape

The net bearing capacity was calculated from the following equation

$\mathrm{q}_{\text {ult }}=\mathrm{qu}+\left(\gamma_{\mathrm{n}}+\mathrm{D}_{\mathrm{f}}\right)=7.27 \mathrm{~kg} / \mathrm{cm}^{2}$

and the safety bearing capacity was determined

$\mathrm{q}_{\text {all }}=\mathrm{q}_{\mathrm{ult}} / \mathrm{FS}$

where FS is safety coefficient. Considering FS=4

$\mathrm{q}_{\text {all }}=1.82 \mathrm{~kg} / \mathrm{cm}^{2}$

is obtained.The maximum safety bearing capacity of the soils was determined as 2.01 $\mathrm{kg} / \mathrm{cm}^{2}$ considering $\mathrm{C}=47 \mathrm{kPa}, \Phi=3^{0}$ and $\mathrm{Nc}=5.90, \mathrm{Nq}=1.31, \mathrm{~N} \gamma=0.03$ and $\mathrm{B}=35.0 \mathrm{~m}, \mathrm{Df}=20.0 \mathrm{~m}$, $\mathrm{K} 1=1.12$ and $\mathrm{K} 2=0.46$ in Terzaghi's equation.

\section{Pressiometer test results}

Pressiometer test was applied at the depth between 12.0-36.0 $\mathrm{m}$ to figure out the mechanical properties of the soils. The elasticity modulus ranges from 89.14 to $36.0 \mathrm{~kg} / \mathrm{cm}^{2}$ and the net limit pressure (PL) varies between $0.5-7.0 \mathrm{~kg} / \mathrm{cm}^{2}$. The bearing capacity was calculated from the following equation

$\mathrm{q}_{\text {ult }}=\mathrm{k}^{*}\left(\mathrm{PL}^{*}\right)_{\mathrm{c}}$

where,

$\mathrm{k}=1+0.4^{*}(\mathrm{~B} / \mathrm{L}), \mathrm{B}=35.0 \mathrm{~m}, \mathrm{~L}=\mathrm{D}_{\mathrm{f}}=20.0 \mathrm{~m}$, and $\left(\mathrm{PL}^{*}\right)_{\mathrm{c}}$ is the geometric mean of $\left(\mathrm{PL}^{*}\right)$ values. The Boring log of SK-1 is given in Fig 8., and bearing capacity and the safety bearing capacity determined from the boring log are given in Table 8.

Table 8 . Bearing capacity and the safety bearing capacity values determined from pressiometer test conducted in bore-hole SK-1

\begin{tabular}{|c|c|c|c|c|c|}
\hline Depth & $\begin{array}{l}\text { Net limit } \\
\text { pressure } \\
\left(\mathrm{PL}^{*}\right)\end{array}$ & \multirow[t]{2}{*}{$\mathrm{k}$} & $\left(\mathrm{PL}^{*}\right)_{\mathrm{c}}$ & $\begin{array}{l}\text { Bearing } \\
\text { capacity }\end{array}$ & $\begin{array}{c}\text { Safety } \\
\text { bearing } \\
\text { capaciy }\end{array}$ \\
\hline (m) & $(\mathrm{kPa})$ & & $\mathrm{kPa}$ & $(\mathrm{kPa})$ & $(\mathrm{kPa})$ \\
\hline 12 & 175 & \multirow{5}{*}{1.23} & \multirow{5}{*}{208} & \multirow{5}{*}{256} & \multirow{5}{*}{128} \\
\hline 14 & 200 & & & & \\
\hline 28 & 275 & & & & \\
\hline 34 & 200 & & & & \\
\hline 36 & 200 & & & & \\
\hline
\end{tabular}

\section{Compaction results determined by Pressiometer tests}

The amounts of the compaction of the soils for the load $60 \mathrm{kPa}$ applied to soils for the foundation width $B=35 \mathrm{~m}$ and depth $\mathrm{L}=60 \mathrm{~m}$ were calculated between $3.9-1.4 \mathrm{~cm}$. 


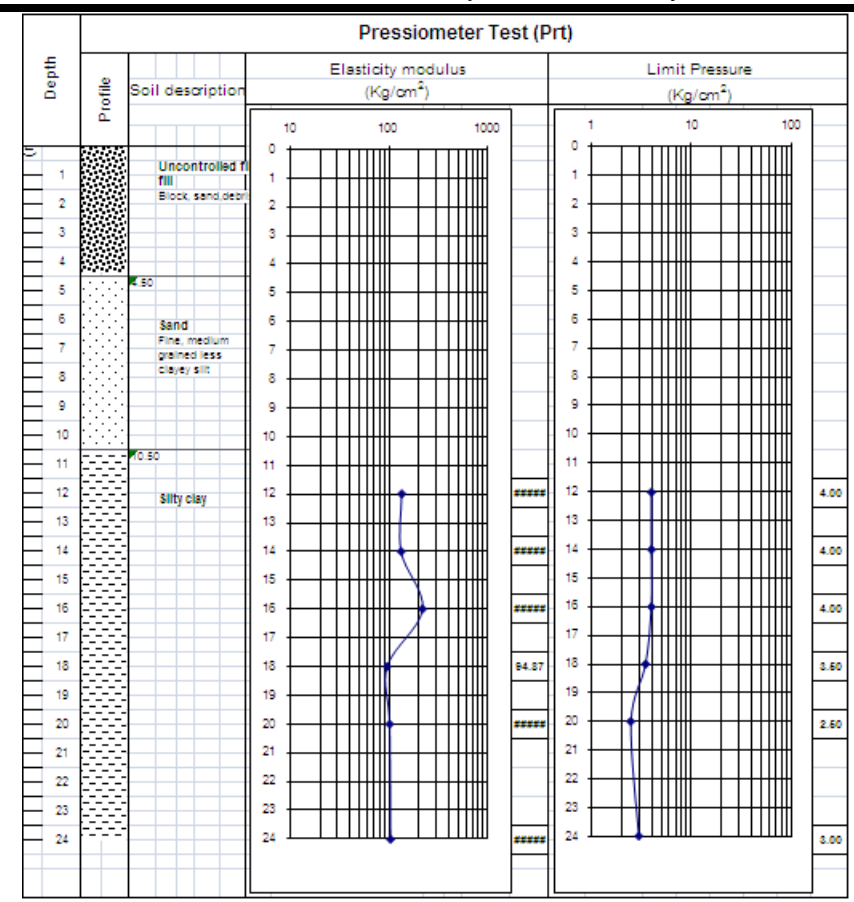

Fig. 8. Boring log of bore-hole SK-1

\section{Bearing Coefficient results}

The bearing coefficients in vertical direction were calculated using the SPT $\mathrm{N}_{30}$ values determined in bore-holes SK-2, SK-4, and SK-5 with the following equation (Meyerhof 1965)

$\mathrm{Ks}=0.75 \times \mathrm{N}_{30}\left(\mathrm{mN} / \mathrm{m}^{3}\right)$

The calculated vertical bearing coefficient values for bore-hole SK-2 are given in Table 9 as $\left(\mathrm{t} / \mathrm{m}^{3}\right)$

Table 9. Calculated vertical bearing coefficients for bore-hole SK-2.

\begin{tabular}{|c|c|c|}
\hline Depth (m) & SPT N $_{30}$ & Vertical bearing coefficient $\left(\mathrm{t} / \mathrm{m}^{3}\right)$ \\
\hline 18.00 & 23 & 1692 \\
\hline 19.50 & 23 & 1692 \\
\hline 21.00 & 24 & 1766 \\
\hline 22.50 & 27 & 1987 \\
\hline 24.00 & 24 & 1766 \\
\hline 25.50 & 28 & 2060 \\
\hline 27.00 & 27 & 1987 \\
\hline 28.50 & 30 & 2207 \\
\hline 30.00 & 30 & 2207 \\
\hline
\end{tabular}

\section{Engineering Analysis and Evaluations \\ Classification of decomposed soil types}

According to 'Regulation about the Structures that will be Built in Disaster Regions, 2007' and Turkish Earthquake Code, the local soil class of the soils were determined as 'Z4', soil group 'D', effective soil acceleration coefficient $\mathrm{A} 0=0.40$ ', building importance factor ' $\mathrm{I}=1.5$ ' and the spectrum characteristic periods TA and TB as 0.20 and 0.90 (s). Soil dominant vibration period and soil magnification were calculated as 0.62-0.63 (s) and 3.0 respectively. 
Results of liquefaction Analysis

Liquefaction occurs in saturated soil composed of uniform grained silt and fine sand. Liquefaction occurs (based on the Chinese criteria) to have the following characteristics (Seed et al. 1983; Wang 1979);

Percent finer than $0.005 \mathrm{~mm}$ (5 microns) «15\%

Liquid limit < $35 \%$

Water content > $90 \%$ of LL

SM soils are located in the upper levels and CL-CH soils in lower layers. The sand unit with the thickness of $11 \mathrm{~m}$ will be removed with the foundation excavation that will be $20 \mathrm{~m}$ in the investigation area. For that reason liquefaction is not envisaged.

\section{Seismicity of the region}

The study area is located in the Marmara region which is an active tectonic zone of Turkey characterized by the transition between the dextral strike-slip regime of the North Anatolian Fault (NAF) and the extension regime of the Aegean Sea. The NAF with a length of $1500 \mathrm{~km}$ is the most active component in the tectonic evolution of Anatolia, and is one of the most active and largest strikeslip faults in the world (Ulutaş and Özer 2010). The last destructive earthquakes in NAF and in the vicinity of the site were the 1999 Izmit (Mw 7.4) and the 1999 Duzce (Mw 7.2) earthquakes. The earthquakes caused heavy damage in the region between Adapazarı, Hendek, Akyazı and Arifiye. And also the Kocaeli and Düzce earthquakes highlighted the potential effects of local site conditions on the amplification of ground motions and provided the most extensive earthquake data sets ever recorded in Turkey (Ulutaş et al. 2011).

Ulutaş (2006) assessed the spatial distributions of seismicity and seismic hazard for Marmara region, Northwestern part of Turkey. The earthquake frequency-magnitude relationship is a known way to examine the seismic activity level in any seismogenic area . The frequency-magnitude distribution of earthquakes introduced by Ishomoto and Lida (1939) and Gutenberg and Richter(1944), can be formulated as:

$\log 10 \mathrm{~N}=\mathrm{a}-\mathrm{bM}$

where $\mathrm{N}$ denotes the exponential distribution of the cumulative number of earthquakes for a single magnitude M, and "a" and "b" are constants describing the activity and slope, respectively. Ulutaş (2006) divided the Marmara region into 9 subregions according to the seismotectonic properties of the areas for the estimation of seismicity parameters. The b value from the Gutenberg-Richter frequencymagnitude distributions was calculated by the classic way and the new alternative method both using the least squares approach. According to the Ulutaş (2006) calculations corresponding to the study area, the a value is found to be equal to 4.26 and $b$ value is found to be equal to 0.57 based on the compiled earthquake catalog by Ulutaş et al. (2003) for the period of 1901-2001. The calculated a and $\mathrm{b}$ value show the relation to the tectonics of the area and earthquake activity. The sets of recurrence parameters (a, b-value and Mmax) were estimated for the seismotectonic sources in Marmara region. The recurrence period of 6.0, 6.5 and 7.0 magnitude earthquakes were determined as 47, 66 and 168 years respectively (Ulutaş et al. 2003) 


\section{CONCLUSION}

The geophysical results revealed three subsurface layers within the investigation area comprising of topsoil, weathered layer and partially weathered layer. The topsoil is thin with the thickness varying 3.78-4.52m and consisted of clay/silt/sand while the weathered layer composed of silty sand with the thickness range from 11.5-14.5 m. The partly weathered layer is formed of silty clayey sand. There is no evident of geological feature such as intensive fault/fracture within the geologic layers. The seismic refraction studies show that the soil layers are of low seismic velocities. The geotechnical results show that the soils are generally of medium natural water content and high clay content as revealed by the percentage passing $0.075 \mathrm{~mm}$. SPT $\mathrm{N}_{30}$ values varying between $13-32$ indicate that the consistency of soils is ranged from 'stiff to hard'. Since the plastic index of the soils within the area are between 26.71-36.1\%, the soil can be judged to be 'plastic-very plastic', have dry consistency as 'mediumhigh', hence, the soils are expected to exhibit 'medium-high' swelling potential.

Deduction from the above is that, the partly weathered layer may be related as relatively good as a foundation material. The foundation of the proposed civil structure can be hosted by this formation. The nature of this layer has to be considered in the design of the foundation.

\section{REFERENCES}

Akintorinwa OJ, Adeusi FA (2009) Integration of geophysical and geotechnical investigation for a proposed lecture room complex at the Federal University of Technology, Akure, SW, Nigeria, Journal of Applied Science 2(3), 2009. 241-254

ASTM, American Society for Testing and Material (1985) Annual Book of ASTM Standards Soil and Rock, Building Stones, Section-4, Construction, V.04.08, ASTM Publication, 972, 166-194

Bozkurt A, Kurtulus C (2009) Integrated geological, geophysical and geotechnical exploration for site characterization in Alikahya region, (NW Turkey), Uygulamali Yerbilimleri Dergisi, say1, C8, 1-17

Gibbs HJ, Holtz WG (1957) Identification and Classification of Soils An Appraisal, and Statement of Principles ASTM-STP 113 American Soc. for Test and Mat Philadelphia 3-24, 85-91

Gutenberg B, Richter CF (1944) Frequency of earthquakes in California. Bull. Seismol. Soc. Amer, 34, 185-188

Ishomoto, M., Lida, K., 1939. Observations of earthquakes registered with the micro- seismograph constructed recently. Bulletin of the Earthquake Research Institute 17, 443-478.

Kurtulus C, Bozkurt A, Endes H, Alkan MA (2010) Engineering and physical characteristics of the Akveren formation, NW of Turkey, 14 ECEE, 1, 645

Leonards GA (1962) Foundation Engineering Mc. Graw-Hill Book Company 11363 NewYork USA 3-24, 85-91

Luna, R, Jadi, H (2000) Determination of dynamic soil properties using geophysical methods. Proceed-ings of the First International Conference on the Ap-plication of Geophysical and NDT Methodologies to Transportation Facilities and Infrastructure-Geophysics 2000. Federal Highway Administration, Saint Louis, MO. Paper No. 3 -1, 15 
Meyerhof G (1965) Shallow foundations. Journal of Soil Mechanics and Foundations Division, 91(SM2): $21-31$

Momoh LO, Akintorinwa O, Olorunfe MO (2008) Geophysical Investigation of Highway Failure - A Case Study from the Basement, Complex Terrain of Southwestern Nigeria, Journal of Applied Sciences Research, 4(6): 637-648

Ozcep F, Guzel M, Kepekci D, Laman M, Bozdag S, Cetin H, Akat A (2009) Geotechnical and Geophysical studies for wind energy systems in earthquake-prone areas: Bahce (Osmaniye, Turkey) case. International Journal of Physical Sciences Vol. 4. (10), 555-561

Peck R, Hanson WE, Thornburn TH (1953) Foundation Engineering: John Wiley \& Sons, New York, 410

Seed HB, Idriss IM, Arango I (1983) Evaluation of Liquefaction Potential using Field Performance data. Journal of Geotechnical Eng, ASCE, 109(3); 458-482

Soupios PM, Papazachos CB, Vargemezis G, Fikos I (2005) Application of seismic methods for geotechnical site characterization, International Workshop in Geoenvironment and 1 Geotechnics, September 2005, Milos island, Greece, 1-8

Sowers GF (1979) Intraductory Soil Mechanics and Foundations 4 th. Edition Collier, MacMillian International edition McMillian Publishing Company New York USA

Ulutaş E, Güven IT, Irmak TS, Sertçelik F, Tunç B, Çetinol T, Caka D, Özer MF, Kenar Ö (2003) Doğu Marmara Bölgesi İçin Deneysel En Büyük Yatay İvme Uzaklık Azalım İlişsisi ve İzmit'in Probabilistik Deprem Tehlikesi., Kocaeli 2003 Deprem Sempozyumu, Kocaeli. Bildiri Özetleri Kitabı, 133 (In Turkish)

Ulutaş E (2006) Seismic Zonation of Eastern Marmara Region, Seismic Microzonation of Kocaeli Province and İzmit Urban Area, Thesis (PhD), University of Kocaeli, Institute of Science and Technology, Kocaeli (In Turkish)

Ulutaş E, Özer MF (2010) Empirical attenuation relationship of peak ground acceleration for Eastern Marmara region in Turkey. Arab. J. Sci. Eng., 35, 187-203

Ulutaş E, Coruk O, Karakas A (2011) A Study Of Residuals For Strong Ground Motions In Adapazari Basin, Nw Turkey, By Ground Motion Predictions Equation (GMPEs), Studia geoph, et geod., 55.

Wang W (1979) Some Findings in Soil Liquefaction, Report Water Conservancy and Hydro-electric Power Scientific Research Institute, Beijing, China, 1-17 